\title{
Domestic Violence in Zora Neale Hurston's Their Eyes Were Watching God: A Feminist Reading
}

\author{
Parmis Tasharofi \\ Faculty of Humanities, Department of English Language and Literature \\ Arak Branch, Azad University, Iran \\ E-mail: Parmis6485@yahoo.com
}

Received: 11-02-2014

Accepted: 19-03-2014

Published: 01-07-2014

doi:10.7575/aiac.ijalel.v.3n.4p.120

URL: http://dx.doi.org/10.7575/aiac.ijalel.v.3n.4p.120

\begin{abstract}
Zora Neale Hurston's Their Eyes Were Watching God is one of the acclaimed boldly feminist novels of the $20^{\text {th }}$ century. In general, this article draws on feminism and what looms large in feminism which is called sexism. In particular it focuses on domestic violence as a major sexist oppression. Domestic violence aroused by jealousy, anger, coercion, humiliation, threatening is manifest in verbal and physical abusing of women. Hurston skillfully depicts her heroine's undergoing of domestic violence by her husbands, each in different ways. This article aims to show that how the black heroine's battling with this violence purports to feminism and self-discovery of women.
\end{abstract}

Keywords: Patriarchy, Domestic household, Domestic violence, Sexism, Feminism

\section{Introduction}

\subsection{Feminism, Sexism, Domestic Violence}

As Bressler states, one of the most significant developments in literary studies in the second half of the twentieth century, feminist criticism advocates equal rights for all women in all areas of life: socially, politically, professionally, personally, economically, aesthetically, and psychologically. According to him, the adherents of feminist criticism are women and some men who are struggling to discover who they are, how they arrived at their present situation, and where they are going. In their search, they value the individual person, validating the individual as opposed to the group. Their search at times is political because their aims is to discover and change both themselves and the world in which they live, a world that must learn to validate all individuals, all cultures, and all subcultures as creative, aesthetic, and rational people who can contribute to their societies and their world (2007). Feminist critics argue that literature plays a central role in the development of social attitudes toward women and of women's attitudes toward themselves (Booker, 2007).

In feminism, sexism is regarded. Bell hooks claims that sexist oppression is the foundation of patriarchal culture and that it should be the main regard of progressive feminism (as cited in Castle, 2007). Sexism is the discrimination against, on the grounds of sex. According to hooks, in examination of the black female experience, sexism looms as large as an oppressive force in the lives of black women (1981). As "Sexism" explains, sexism can enlarge in different forms. Domestic violence is a prevalent form of sexism in domestic households (2014).

According to Lynda Marie Jordan, domestic violence is a pattern of abusive behavior in which a person uses coercion, deception, harassment, humiliation, manipulation to maintain power over his intimate partner (2002). The Centers for Disease Control and Prevention (CDC) redefined the term "domestic violence" as "intimate partner violence" or IPV (Jordan, 2002, p.15) which includes the acts of violence occurring between current or former spouses, boyfriends or girlfriends. Moreover it includes violence between persons who have a current or former marital, dating, or cohabiting relationship (Hampton, Magarian, and Oliver 2003). According to Jordan, domestic violence crosses ethnic, racial, age, national origin, sexual orientation, religious and socioeconomic lines. She adds that the majority of victims of domestic violence in heterosexual relationships are women. According to her, African-Americans experience domestic violence at a high rate and that the most permissible form of violence is for African-American woman by her African-American man (2002).

Zora Neal Hurston is regarded as one of the great African-American writers in the $20^{\text {th }}$ century Harlem Renaissance. This article gives her Their eyes were watching God a critical view according to Feminist literary theory. According to Weems, as the novel suggests, a great obstacle in relation to male/female harmony is sexism (1989). Janie, the heroine of the novel, got married three times and in her marriages she underwent domestic violence in different forms and out of different reasons. This research provides us with samples taken from the novel which shed light on Janie's undergoing of domestic violence in her households. Her battling with this violence with each husband made her a feminist woman and has made the novel a feminist novel. 


\section{Discussion}

\subsection{Janie and Logan Killicks}

According to Marks in his article named "sex, Violence, and Organic Consciousness in Zora Neale Hurston's Their Eyes Were Watching God," Janie is involved in four love relationships: her first sexual encounter with Johnny Taylor, her first marriage to Logan Killicks, and her subsequent marriages to Joe Starks and Vergible Tea Cake Woods. Each relationship, notes Marks, is different from the others and there are two in which Janie is passionately involved, which are her short-lived romance with Johnny Taylor and her marriage to Tea Cake, and there are two in which she is restricted and unhappy, which are her marriages to Logan Killicks and Joe Starks. Thus, as Marks concludes, Janie's four loves fall into two categories: those of passion and those of control (1985).

Each category is characterized by particular sign structures. To the passionate relationships, Hurston attaches metaphors of natural fertility and sexuality and to the control relationships she attributes physical deformity, decay, technological, non-sexual productivity, and accumulation of wealth and power (Marks, 1985).

Also the two different types of relationships, Marks contends, allow Janie two kinds of interaction with her community. These interactions are classified under the two categories of work and play. According to Marks, Johnny and Tea Cake represent opportunity for Janie to play, that is, to move out from herself and to participate in an organic community. He adds that Tea Cake's community "on the Glades," is an organic community which is free of legislative power structures-characteristic of a mechanistic community. He concludes that Logan and Joe remove her from genuine communal activity and require her to work and to support the class distinctions of bourgeois capitalism. Janie is removed from her grandmother to work on Logan's land. For her, "It was a lonesome place like a stump in the middle of the woods where nobody had ever been" (Hurston, 2004, p.25). As Marks states, Though Logan considers what he has done to improve Janie's social and economic status a favor, claiming that he has taken her from "de white folk's back-yard," his lack of play and passion makes her feel isolated and confined (1985).

Logan takes "nothin' to count but sow-belly and corn-bread." He places more importance on maintaining the farm than on sustaining his marriage (Marks, 1985). "A whole lot of mens will grin in yo' face," he tells Janie, "but dey ain't gwine tuh work and feed yuh" (Hurston, 2004, p. 30). He starts by making her feel indebted to her and the exercise of creating this feeling on her can be the starting point of domestic violence in their relationship.

Though Killicks provides for both Janie and himself during the first months of their marriage, he gradually expects her to do a share of the labor.

Long before the year was up, Janie noticed that her husband had stopped talking in rhymes to her. He had ceased to wonder at her long black hair and finger it. Six months back he had told her, 'If Ah kin haul de wood heah and chop it up fuh yuh, look lak you oughta be able tuh tote it inside. Mah fust wife never botheres me 'bout choppin' no wood nohow. She'd grab dat ax and sling chips lak uh man. You done been spoilt rotten'. (Hurston, 2004, p.28)

Joe's so-called favors and his insults made Janie reply him in a threatening way: "If you can stand not to chop and tote wood Ah reckon you can stand not to git no dinner. 'Scuse mah freezolity, Mist' Killicks, but Ah don't mean to chop de first chip." Janie's threatening tone and words maintained the play of verbal abusing in their conversation: "Aw you know Ah'm gwine chop de wood fuh yuh. Even if you is stingy as you can be wid me. Yo' Grandma and me myself done spoilt yuh now, and Ah reckon Ah have tuh keep on wid it" (Hurston, 2004, p.28).

Racine in his article, "voice and interiority in Zora Neale Hurston's Their Eyes Were Watching God" claims that Logan and Janie speak peripherally and their conversations are not intimate in a loving fashion. He states that their discussions focus on daily living activities like chopping wood and peeling potatoes (1994). Well their relationship from the very beginning becomes polluted with domestic violence in the form of verbal abuse.

Before Janie leaves him for Joe, Logan proposes that she, like him, could run a plow: "Ah needs two mules dis yeah. Taters is goin' tuh be taters in de fall. Bringin' big prices. Ah aims tuh run two plows, and dis man Ah'm talkin' 'bout is got uh mule all gentled up so even uh woman kin handle 'im" (Hurston, 2004, p.28). Racine observes that when Logan wants Janie to work by his side in the fields, he tells her that he has found a "gentle mule" to suit her. He wants her in the fields as Tea Cake does later in the novel for her company so that they might build their security together. But Logan does not ask her to work by his side, as Tea Cake will later. Logan orders her (1994).

Indeed, Logan puts her on a pedestal in his patriarchal marriage. On his pedestal Janie could do no more than being in the house and fulfilling her responsibilities there such as cooking and peeling the potatoes or maintaining the farm by doing the tasks such as plowing with the mule that he has bought for her or chopping the woods and toting them inside the house. As Tyson claims, the wrong by being placed on a pedestal is that for one reason pedestals are small and leave a woman very little room to do anything but fulfill the prescribed role and that also pedestals are shaky and one can easily fall off a pedestal (2006). As it is clear, Logan leaves Janie very little room to do anything but her prescribed roles in her marriage with him.

Staple observes that among the reasons for marital violent conflicts are disputes over jealousy: "Jealousy is most likely the primary cause of spousal violence (as cited in Hapmton, et al., 2003, p. 544). And when Janie meets Jody and becomes motivated by him to leave her husband for him, we see that the jealousy-aroused by Logan-as one of the most important causes of domestic violence invites more verbal abusing in their marriage. When Janie meets Jody on the road and was asked to leave Logan for him, she debates the matter with Logan the very night and makes Logan 
angry: "Ah thought you would 'preciate good treatment. Thought Ah'd take and make somethin' outa yuh . . . you won't git far and you won't be long, when dat big gut reach over and grab dat little one, you'll be too glad to come back here" (Hurston, 2004, pp. 29-30).

From this point, Logan feels insecure, jealous and threatened and their relation is not only better but worse: "Janie!" Logan called harshly. "Come help me move dis manure pile befo' de sun gits hot. You don't take a bit of interest in dis place. 'Tain't no use in foolin' round in dat kitchen all day long." And Janie responds: "You don't need mah help out dere, Logan. Youse in yo' place and Ah'm in mine." The argument continues: "You ain't got no particular place," and Logan tells her, "It's wherever Ah need yuh" (Hurston, 2004, p.30). Quick at repartee Janie tells her,

Mah mamma didn't tell me Ah wuz born in no hurry. So whut business Ah got rushin' now? Anyhow dat ain't whut youse mad about. Youse mad 'cause Ah don't fall down and wash-up dese sixty acres uh ground yuh got. You ain't done me no favor by marryin' me. And if dat's whut you call yo'self doin', Ah don't thank yuh for it. (Hurston, 2004, p.30)

Logan threatens to "take holt uh dat ax . . . and kill" her:

Don't you change too many words wid me dis mawnin', Janie, do Ah'll take and change ends wid yuh! Heah, Ah just as good as take you out de white folks' kitchen and set you down on yo' royal diasticutis and you take and low-rate me! Ah'll take holt uh dat ax and come in dere and kill yuh! You better dry up in dere! Ah'm too honest and hard-workin' for anybody in yo' family, dat's de reason you don't want me! . . Ah guess some low-lifted nigger is grinnin' in yo' face and lyin' tuh yuh. God damn yo' hide! (Hurston, 2004, p.30)

According to Racine, Logan can provide his young bride "protection" and financial security. He asserts that his material success contrasts with his emotional inadequacy. As Racine contends, Hurston portrays two people, different in their desires and concerns, unable to express true emotions or passion. For Janie, a teenage girl, passion is a dream. For Logan, passion has been suppressed for security that Janie does not understand (1994).

According to Wolfenstein, Logan does quite a bit of carrying the chips but he expects the same and more of Janie. He notes that when Janie puts him in his place, he comes close to hitting her (2008). One source claims that according to researchers' report, women are most at risk for domestic violence during those times that they seek to terminate an intimate relationship with a husband or boyfriend. It argues that as a result it is not uncommon for African-American men to resort to violence as a means of expressing anger about their partner's decision to terminate the relationship or as a means of retaliating for their partner's being sexually unfaithful (Hampton, et al., 2003).

\subsection{Janie and Joe Starks}

Readers are probably relieved when Janie leaves Logan for the enthusiastic and energetic Joe since she has escaped the mule and plow. Joe arouses Janie's interest by offering her a position as comfort in life when he says to her, "You behind a plow! You ain't got no mo' business wid uh plow than uh hog is got wid uh holiday! You ain't got no business cuttin' up no seed p'taters neither. A pretty doll-baby lak you is made to sit on de front porch and rock and fan yo'self and eat p'taters dat other folks plant just special for you (Hurston, 2004, p. 29).

Joe presents the opportunity for Janie to escape from Logan but his relationship with her is one of control rather than passion. Marks argues that Hurston dissociates Joe from the things which are for Janie the emblems of love: "Janie Pulled back a long time because he did not represent sun-up and pollen and blooming trees, but he spoke for far horizon. He spoke for change and chance" (Hurston, 2004, p.29).

Like Logan, Joe holds a position of power and respect in his community. Immediately upon his arrival in Eatonville, he establishes himself as mayor and begins to structure a town centered round himself and his store. As he makes Eatonville into a modern community, he directs its citizens through his power of persuasion. Some of the men in town say of Joe that "he loves obedience out of everybody under de sound of his voice." Others complement others and say, "You kin feel a switch in his hand when he's talkin' to yuh ..." (Hurston, 2004, p.40).

Marks states that Joe brings technological advances to Eatonville and the most exemplary is the street lamp which signifies his attempt to govern natural processes. Marks contends that Hurston considers the kind of social system Joe establishes to be oppressive (1985).

Janie's interest in Joe abates, for his voice comes to depend "largely on shutting up hers." When Joe is elected mayor and the townspeople request to have a few words from the first lady, Joe forbids: "Thank yuh fuh yo' compliments, but mah wife don't know nothin' 'bout no speech-makin'. Ah never married her for nothing' lak dat. She's uh woman and her place is in de home'. Janie made her face laugh after a short pause, but it wasn't too easy" (Hurston, 2004, p.37).

This conversation is indeed the starting point in inviting domestic violence in their household. He defines her place and suppresses her voice. She is stunned but suppresses her real feelings and tries to be as silent as the grave and smiles. Witnessing no resistance from her, Starks is quite pleased. Here we are reminded of Kate Millett's sexual politics. According to Millett's concept of sexual politics, feminine gender is created by patriarchy which asserts that men should be domineering while women must be passive and humble (as cited in Bressler, 2007, pp. 173-174). This refers to the operations of power relations in society. Joe's claim that a "woman's place is at home" is a vivid example of his being the one enacting the sexual politics in his patriarchal society within his marriage with Janie. He as a patriarchal man indoctrinates to Janie to surrender to the very conventional notions of gender roles practiced in a patriarchal society. 
Previously, when Joe proposes to Janie, he says "kiss me and shake yo' head. When you do dat, yo' plentiful hair breaks lak day" (Hurston, 2004, p.29). Yet once they marry, he insists that she covers her luxurious hair with a head rag:

That was because Joe never told Janie how jealous he was. He never told her how often he had seen the other men figuratively wallowing in it as she went about things in the store. And one night he had caught Walter standing behind Janie and brushing the back of his hand back and forth across the loose end of her braid ever so lightly so as to enjoy the feel of it without Janie knowing what he was doing. ... He felt like rushing forth with the meat knife and shopping off the offending hand. That night he ordered Janie to tie up her hair around the store. (Hurston, 2004, p.43)

Janie must wear a head rag because her beauty is for him alone to behold: "She was there in the store for him to look at, not those others" (Hurston, 2004, p.43). Joe constantly uses coercion to maintain power over his wife by insinuating that she covers her hair.

Joe's quest for marital dominance deprives Janie of communal interaction. When the townspeople gather outside his store, Janie is forbidden to join in the conversation or tell stories of her own:

Janie loved the conversation and sometimes she thought up good stories on the mule, but Joe had forbidden her to indulge. He didn't want her talking after such trashy people. 'you'se Mrs. Mayor Starks, Janie. I god, Ah can't see what uh woman uh yo' stability would want tuh be treasurin' all dat gum-grease from folks dat don't even own de house dey sleep in. Tain't no earthly use. They's jus' some puny humans playin' round de toes un Time ... Joe would hustle her off inside the store to sell something. Look like he took pleasure in doing it. (Hurston, 2004, p.43)

Cixous' claim that women in the binary thought of activity/passivity occupies the right side in patriarchal societies (as cited in Tyson, 2006) is manifest when Joe always assigns the passive role to Janie supporting the left side of his patriarchal thinking. According to Racine, Joe wants a wife who stays at home and helps him in his store. So Janie is allowed only to associate with the community members at a superficial level. Racine claims that whether out on a farm or withdrawn into a store, both Logan and Joe remove Janie from the community. He concludes that in many ways, Janie is just another of his possessions (1994).

One afternoon, when the townsfolk engage in a game of mule-baiting, Jody buys the mule, making Janie happy. The mule becomes town's pet living in the front yard of the store leading a life of ease but when the mule finally dies of old age and a funeral had been held for it, Jody prohibits Janie from attending the funeral due to her status:

You wouldn't be seen at uh draggin'-out, wouldja? Wid any and everybody in uh passle pushin' and shovin' wid they no-manners selves? Naw, naw. . . . Ah'm uh man even if Ah is de Mayor. But de mayor's wife is somethin' different again. Anyhow they's liable tuh need me tuh say uh few words over de carcass, dis bein' uh special case. But you ain't goin' off in all dat mess uh commonness. Ah'm surprised at yuh fuh askin'. (Hurston, 2004, p.46)

Well with Joe, it has been always resignation and acceptance. He interprets her silence as tacit compliance since she has not the slightest objection. Joe tries to make Janie be her "angel in the house," the concept introduced by Gilbert and Gubar (as cited in Bressler, 2007, p.178) when he denies Janie of speaking for his election as the mayor, participating in communal activities, attending the mule's funeral, and so forth. By making her his angle in his house, he tries to command her to conform to the virtues associated with patriarchal femininity. As the angle in the house, he expects her to please her husband by attending his every command. She must have no needs of her own but to serve her family. He wants to teach her to find the utmost contentment through only serving him.

One day a woman arrives and asks Jody for documentation of the food stock, causing a dispute between Jody and Janie over its location. Couldn't find the order, Jody accuses Janie: "You ain't put it where Ah told yuh tuh. If you'd git yo' mind out de streets and keep it on yo' business maybe you could git somethin' straight sometimes." And then he adds: "Wid you heah, Ah oughtn't tuh hafta do all dat lookin' and searchin'. Ah done told you time and time agin tuh stick all dem papers on dat nail! All you got tuh do is mind me. How come you can't do lak Ah tell yuh?" Then we see Janie speaks out: "You sho loves to tell me whut to do, but Ah can't tell you nothin' Ah see!" Then again Jody tries to answer back: "Dat's 'cause you need tellin', it would be pitiful if Ah didn't. Somebody got to think for women and chillum and chickens and cows. I god, they sho don't think none theirselves." When Janie said: "Ah know uh few things, and womenfolks thinks sometimes too," Jody bullied her: "Aw naw they don't. They just think they's thinkin'. When Ah see one thing Ah understands ten. You see ten things and don't understand one" (Hurston, 2004, p.51). As it is clear, Joe constantly humiliates Janie, the fact which triggers domestic violence.

Over this long dispute, Janie tries to answer with comments about his deficiencies. As usual Joe prevails and Janie gives up: "She fought back with her tongue but it didn't do her any good. ... He wanted her submission and he'd keep on fighting until he felt he had it" (Hurston, 2004, p.51).

According to Marks, Joe also expresses an intolerance for playfulness and places more value on social position and monetary gain than on romance (1985). He complains that his people should "get mo' business in 'em and not spend so much time on foolishness" (Hurston, 2004, p.47). His emphasis on work and his desire to provide Janie with a position of respect within the community inhibits the couple's sexuality. Joe's behavior makes her life seem empty and mechanical. Later in their marriage, Joe's unceasing demand for her submission stifles the couple's sexuality: "So 
gradually, she pressed her teeth together and learned to hush. The spirit of the marriage left the bedroom and took to living in the parlor. ... The bed was no longer a daisy-field for her and Joe to play in. It was a place where she went and laid down when she was sleepy and tired" (Hurston, 2004, p.51).

Joe has always enjoyed Janie's cooking. Then one evening, the meal simply didn't turn out right and Joe "slapped Janie until she had a ringing sound in her ears ...." The slap went to her heart with a sharp stab. She stood still where he left her, until "something fell off the shelf inside her ... Then she went inside there to see what it was. It was her image of Jody tumbled down and shattered. ... She had no more blossomy openings dusting pollen over her man. ... She found that she had a host of thoughts she had never expressed to him, and numerous emotions she had never let Jody know about" (Hurston, 2004, p.51).

As Goldstein contends, Joe saves Janie from Logan but imposes on Janie a harsh self-division. Like the town, Janie keeps her resentment of Jody to herself and divides into a silent but meaningful private self and a conventional but insignificant public self: "She had an inside and an outside now and suddenly she knew how not to mix them" (Hurston, 2004, p.51). As Wolfenstein declares, Hurston assumes that public speech overcomes the division between the character's public and private selves. According to Wolfenstein, still, to overcome the self-division imposed by Jody, Janie struggles to engage in public talking. Her struggle culminates when later on we see that she calls him an old sexually impotent man. He concludes that Their Eyes Were Watching God shows that the marital difficulties faced by the female characters impose on them a self-division alleviated by public speech (2008).

Another day a customer comes in and demands some tobacco and Janie cuts it wrong, away from the mark. Since Joe has become more cognizant of their age difference, he resents her youth and out of jealousy and insecurity, he attacks her youth: "A woman stay round uh store till she get old as Methusalem and still can't cut a little thing like a plug of tobacco! Don't stand der rollin' yo' pop eyes at me wid yo' rump hangin' nearly to yo' knees" (Hurston, 2004, p.56).

But Time will invite her and as there is a time for keeping quiet and a time for speaking out, she will challenge Joe with words and make clear that he has not completely dominated her. Janie is naturally gifted as is Joe with oral agility and one day she uses that talent to "emasculate" her husband publicly on the porch of their store. According to Wolfenstein, she calls him out in the image of a menopausal woman (2008). With one cutting sentence she cuts Joe of his voice "and that was something that hadn't been done before" (Hurston, 2004, p.56):

Stop mixin' up mah doings wid mah looks, Jody. . . Yeah, Ah'm nearly forty and you'se already fifty. . . . Naw, Ah ain't no young gal no mo' but den Ah ain't no old woman neither. . . But Ah'm uh woman every inch of me, and Ah know it. Dat's uh whole lot more'n you kin say. You big-bellies round here and put out a lot of brag, but 'taint nothin' to it but yo' big voice. Humph! Talkin' 'bout me lookin' old! When you pull down yo' britches, you look lak de change uh life. (Hurston, 2004, p.56)

As a tit for tat, this time Janie humiliates Joe and this humiliation before his friends destroys his public image. Unable to respond to Janie verbally, "he struck Janie with all his might and drove her from the store" (Hurston, 2004, p.56). Once the male feels emasculated, there is a very high probability that he will abuse his wife. Well, it is the second time that the couple have been involved in domestic violence, the second time that Jody hits Janie.

When Jody continues to decline physically, he does not allow Janie to enter his bedroom and take care of him. He does not believe he will die. He wants Janie to leave the room, but she decides to speak to him and tell him that she has been so prodigal and spent-thrift and that she has given him all her naked loveliness. She goes to his bedside and tells the dying man some of the things that should have been said a long time ago:

Naw, Jody, it wasn't because Ah didn't have no sympathy. Ah had uh lavish uh dat. Ah just didn't never git no chance tuh use none of it. You wouldn't let me.... You done lived wid me for twenty years and you don't half know me at all. And you could have but you was so busy worshippin' de works of yo' own hands, and cuffin' folks around in their minds till you didn't see uh whole heap uh things yuh could have. . . You changes everything but nothin' don't change you - not even death. Naw, you gointuh listen tuh me one time befo' you die. . . . Listen, Jody, you ain't de Jody ah run off down de road wid. . . . Ah run off tuh keep house wid you in uh wonderful way. But you wasn't satisfied wid me de way Ah was. (Hurston, 2004, p.60)

In spite of the sincerity of Janie's pleas that he should realize that their marriage has not brought them the happiness they both desired when they took that train to Eatonville, Jody still feels unrepentant and attacks her with loud words of abuse: "Shut up! Ah wish thunder and lightenin' would kill yuh!" (Hurston, 2004, p.60). Realizing that her words will not sink into his heart, Janie buried him in reproaches:

And now you got tuh die tuh find out dat you got tuh pacify somebody besides yo' self if you wants any love and any sympathy in dis world. You ain't tried to pacify nobody but yo' self. Too busy listening tuh yo' own big voice. ... All this bowin' down, all dis obedience under yo' voice - dat ain't whut Ah rushed off down de road tuh find out about you. (Hurston, 2004, p. 60)

As Wolfenstein includes, Logan loses his power within the marriage before he is abandoned. Joe dies of kidney failure but Janie as good as kills him (2008).

Freeing her hair from the kerchief that has bound it, Janie sees herself in the mirror. She was no longer her husband's creation and she began to understand herself as she is strong and beautiful. She "let down her plentiful hair. The weight, the length, the glory was there. She took careful stock of herself, then combed her hair and tied it back up 
again. Then she starched and ironed her face, forming it into just what people wanted to see." Then she opened up the window and cried, "Come heah people! Jody is dead. Mah husband is gone from me" (Hurston, 2004, p.61).

\subsection{Janie and Teacake}

According to Racine, Tea Cake shows her a non-materialistic, day-to-day existence of love and respect between people who are not in a constant state of competition and control (1994).

Tea Cake's behavior is antithetical to Logan and Joe. He is interested in play rather than accumulating more. When he finds that his new wife has two hundred dollars, instead of buying land or saving the money, he uses it to throw a barbecue and dance party: " He never had had his hand on so much money before in his life, so he made up his mind to see how it felt to be a millionaire . . . he decided to give a big chicken and macaroni supper that night, free to all" (Hurston, 2004, p.83).

Tea Cake not only distributes his newly acquired wealth, he also spends it on himself: "Everybody began to holler at the music because the man couldn't play but three pieces. So Tea Cake took the guitar and played himself. . . . So that put him in the notion that he ought to have one. He bought the guitar on the spot " (Hurston, 2004, p.84).

Marks claims that Joe spends the money on a guitar, an instrument of play to be used for gatherings and dances. He argues that rather than accumulating property and distinguishing himself from the remainder of society, Tea Cake concerns himself with active participation in communal rituals of disorder (1985).

Joe believes that his people should spend less time on "foolishness." Tea Cake offers Janie the opportunity to be "foolish" and to break the constraints which Starks impose upon her. The first service Tea Cake performs for Janie is to teach her how to play checkers: "He set it up and began to show her and she found herself glowing inside. Somebody wanted her to play. Somebody thought it natural for her to play" (Hurston, 2004, p.67).

When Tea Cake and Janie leave Eatonville for Everglades, it brings Janie into a community which had been denied her in her earlier marriages. Janie's life with Tea Cake in the Everglades is centered round leisure and festivity as opposed to work and commerce.

Sometimes Janie would think of the old days in the big white house and the store and laugh to herself. What if Eatonville could see her now in her blue denim overalls and heavy shoes? The crowd of people around her and a dice game on her floor! . . . The men held big arguments here like they used to do on the store porch. Only here, she could listen and laugh and even talk some herself if she wanted to. She got so she could tell big stories herself from listening to the rest. Because she loved to hear it, and the men loved to hear themselves, they would "woof" and "boogerboo" around the games to the limit. (Hurston, 2004, p.90)

"On the muck" everything can be "done for a laugh." Even at work Tea Cake and Janie are at play: " all day long the romping and playing they carried on behind the boss's back made her popular right away. It got the whole field to playing off and on" (Hurston, 2004, p.89). According to Marks, in the community "on the Glades," people distance and distinguish themselves from the power structure of the boss-worker system. He claims that economic stability and technological progress are less important to the people "on the muck" than "dancing, fighting, singing, crying, laughing, winning, and losing love every hour. Work all day for money, fight all night for love" (Hurston, 2004, p.89). Marks notes that the life on the muck is the one that Janie's passionate relationship with Tea Cake affirms. According to him, Hurston romanticizes the community on the Everglades as a kind of brotherhood free of constraints and class divisions imposed by a mechanistic, capitalistic society like that of Eatonville (1985).

After a while in the muck, when Janie suspects a woman named Nunkie of desiring Tea Cake, she "learned what it felt like to be jealous." This woman has been affectionate with him over a period of several weeks, and Tea Cake does not seem to ignore her attention. Others notice their interaction as well:

A little chunky girl took to picking a play out of Tea Cake in the fields and in the quarters. If he said anything at all, she'd . . . run away to make him chase her. . . . It kept up for two and three weeks with Nunkie getting bolder all the time. She'd hit Tea Cake playfully and the minute he so much as tapped her with his finger she'd fall against him or fall on the ground and have to be picked up. (Hurston, 2004, p.92)

Later, Janie discovers Tea Cake and Nunkie together in a sugarcane field, and she demands to know what they were doing. He tells Janie that she grabbed his working tickets from his pocket and that he ran after her to get them back. Janie tries to grab Nunkie, but the woman runs away. Janie returns home and "cuts him short with a blow" and this triggered an argument:

They fought from one room to the other. . . . They fought on. . . They wrestled on until they were doped with their own fumes and emanations; till their clothes had been torn away; till he hurled her to the floor and held her there melting her resistance with the heat of his body, doing things with their bodies to express the inexpressible; kissed her until she arched her body to meet him and they fell asleep in sweet exhaustion. (Hurston, 2004, p.92)

Usually the acts of domestic violence occurring between the couples are committed by male partners. When Janie was with Jody, it was only Jody who abused her physically and Janie would only responded to him verbally. With Tea Cake, We see for the first time that Janie herself is fallen prey to jealousy when another woman pursues him and that it is the first time that Janie reacts to her jealousy by hitting him. 
But still there are limits. As Weems claims, for a brief time only, Tea Cake falls into the trap of male domination (1989). Janie and Tea Cake, though they are very much in love, have a series of domestic quarrels fueled by jealousy. When Tea Cake, hurt by the insinuations of Mrs. Turner, beats Janie out of jealousy, Hurston justifies it as a way for Tea Cake to relieve his anxieties. "When Mrs. Turner's brother came and she brought him over to be introduced, Tea Cake had a brainstorm": "Before the week was over he had whipped Janie. Not because her behavior justified his jealousy, but it relieved that awful fear inside him. Being able to whip her assured him in possession. No brutal beating at all. He just slapped her around a bit to show he was boss" (Hurston, 2004, p.99).

According to Marks, Hurston rationalizes Tea Cake's behavior by having other characters, enviously view the beating as something erotic and as a sign of passion that themselves do not have (1985). Racine (1994) claims that those within Tea Cake and Janie's community, perceive slap as a socially acceptable expression of possessive love and authority: "Everybody talked about it the next day in the fields. It aroused a sort of envy in both men and women. The way he petted and pampered her as if those two or three face slaps had nearly killed her made the women see visions and the helpless way she hung on him made men dream dreams" (Hurston, 2004, p.99).

According to Wolfenstein, while each of the actions of domestic violence occurring between Janie and her male partners such as those between Janie and Jody have been spontaneous and direct, Tea Cake's is both indirect and a matter of strategic calculation (2008). After he bits Janie, he tells his friend, "Ah didn't whup Janie 'cause she done nothin', Ah beat her to show dem Turners who is boss. Ah set in the kitchen one day and heard dat woman tell mah wife Ah'm too black fuh her. She don't see how Janie can stand me" (Hurston, 2004, p.99). Critic Michael Awkward reads Tea Cake's act as "one of unmotivated violence ... intended to exhibit to others the extent of his authority over Janie" (as cited in Racine, 1994, 289). According to Wolfenstein, the domestic violence occurring between Janie and Tea Cake shows the two aspects of masculinity which are the tension between the generosity of love and the selfishness of possession (2008). He beats Janie because he does not know how to verbalize his fear of losing her to someone else (Racine, 1994).

But the way that Hurston put the finishing touches on her novel also draws some light on domestic violence. After some troubling times, including a hurricane and a rabid-dog attack, Janie kills Tea Cake in self-defense, thus ending the novel in tragedy. As claimed in "Sexism", again we see another act of domestic violence-killing the other spouse (2014).

According to Racine, Janie has experienced a sense of helplessness. She knows that her husband's illness is incurable and that he will die, yet she decides to live. This is not the decision of a helpless woman, notes Racine, since she must kill her husband in order to stay alive (1994). Emma Dawson suggests that Janie kills the one who represents her "self-fulfillment and self-assertion" (as cited in Racine, 1994). In shooting Tea Cake, concludes Racine, Janie makes the ultimate decision of taking another person's life. Janie's violence is a conscious act of self-defense and a matter of choosing life rather than death. He adds that shooting Tea Cake is Janie's assertion to the world that she has a life worth living whether married or single. Janie is a human being who wants to live and is not too afraid to protect herself. Though she fears Tea Cake's death, she knows that it is inevitable (Racine, 1994). Wolfenstein suggests, when Janie kills him, she splits off this mad dog from the loving man who was unable to keep a leash on it and that she killed the maddened beast which took possession of the man she loved (2008).

Well, Janie enjoyed one and a half years of hedonistic living with Tea Cake but according to Giles, she "will now develop a new method of coping with time-reflective hedonism. She will cultivate memories of sexuality and drama. She needs no new experience because her cup is full" (as cited in Howard, 1982, p.412).

\section{Conclusion}

Janie experienced domestic violence as its prevalent form with her husbands in different ways. Logan abuses her verbally and Joe hits her twice out of a patriarchal stand and Tea Cake only once from a romantic position.

As Wolfenstein concludes, Logan's threats are preoccupying Janie when she decides to leave (2008). Well, that is why we see no acts of domestic violence in the form of physical abuse between them and what we see is only in the form of insulting and cursing each other and each other's generations. They insult each other verbally till they part. Wolfenstein declares that Joe's anxious possessiveness exceeds Logan and the blows that were threatened in the first case are brutally delivered in the second. As he argues, the blows Teacake struck out of insecurity may have marked her for the moment but they left no emotional scars (2008). To me, if Tea Cake flirts with other women, it is to sweeten his love making with Janie and if he beats her, his blows are lovetaps.

Wolfenstein concludes that with Logan and Joe, Janie is a battered wife but with Tea Cake the moment of consciously intended male violence is the exception, not the rule and that Janie is not a battered wife (2008).

Joe and Logan believe that they have done everything possible for their wife and that they treat her well. They assume that since they have provided Janie with house and money, they have provided her with a happy life. In fact, they do not know that a big house does not suffice in making a woman with all her complexities happy inside. They want to create her according to their own desire. Janie is indeed a creation of them and not her true self. This is the fact which leads them to have violence in their households. Though Joe's voice booms as he awakens Eatonville into an active community, it diminishes when he might express his true emotions to his wife. Joe begins by suppressing his wife's voice but in the end his own voice is suppressed when Janie speaks out. Though, Teacake is financially and socially inferior to both Logan and Joe, he has the ability to express his feelings for Janie compared to other men. With Teacake's support and encouragement, Janie strengthens her voice. Tea Cake gives her the chance to enjoy life 
without being a man's mule or adornment. With him she can speak her own mind. With Tea Cake, she may not have much but what she has is a lot. With Joe, It's not that he didn't care for her. It's just that he was a little more involved with someone else-himself. It was the matter of self-love. Joe was just as charming as fake. He doesn't love her the way she needs to be loved. He and Logan consider love as a means to an end. Janie didn't allow them to use her as a means to their ends. She was not supposed to be Logan's mule or Joe's adornment.

Janie's decision to run off with Joe, foreshadows her ability to triumph over patriarchal oppression throughout her life. Also letting herself to fall again in love after Joe, not submitting to mourning and crying and allowing herself once again to explore the beauties of love and life justifies her triumph. And after she commits the worst form of domestic violence and kills Tea Cake, she returns to her town and decides to tell her own story to Pheoby since she doesn't like reading but prefers being read. She wants to tell her story to Pheoby so that Pheoby will tell it to other women and that in this way the women of her community and other communities will learn to live for themselves. Janie does not want to read-her story-but this time wants Pheoby to read her. Her story is indeed not a love story, but a story about love, its ups and downs and all types of violences she confronted in her marriages. Neither giving in to them nor running away from them but battling them is what made her a feminist woman and the novel, a feminist novel.

\section{References}

Bloom, H. (Ed.). (2009). Bloom's Guides: Their Eyes Were Watching God. New York, N.Y : Bloom's Literary Criticism.

Booker, M. K. (1996). A practical introduction to literary theory and criticism. U.S.A: Longman publishers USA.

Bressler, C. E. (2007). Literary criticism: An introduction to theory and practice (4 ${ }^{\text {th }}$ ed.). U.S.A: Pearson Prentice Hall.

Hampton, R., Oliver, W., \& Magarian, L. (2003). Domestic violence in the African American community: An analysis of social and structural factors. Violence against women, 9(5),533-557.doi:10.1177/1077801202250450

Howard, L.P. (1982). Nanny and Janie: Will the Twain Ever Meet? (A Look at Zora Neale Hurston's Their Eyes Were Watching God) Journal of Black Studies, 12(4), (403-412). Retrieved from http://www.jstor.org/stable/2783985

Hurston, Z. H. (2004). Their Eyes Were Watching God. Retrieved from http:// Harper Collins e-books.com

Jordan, L. M. (2002). Domestic violence in the African American community. In S.Sered (Ed.), Religious healing in Boston (15-24). MA: center for the study of world religions, Harvard university, The Divinity school.

Marks, D. R. (1985). Sex, Violence, and Organic Consciousness in Zora Neale Hurston's Their Eyes Were Watching God. African American Review, 19(4), 152-157. Retrieved from http://www.jstor.org/stable/2904277

Racine, M.J. (1994). Voice and interiority in Zora Neale Hurston's Their Eyes Were Watching God. African American Review, 28(2), 283-292. Retrieved from http://www.jstor.org/stable/3042004

Sexism. (2014, January 29). In Wikipedia the free encyclopedia, Retrieved February 7, 2014, from http://en.wikipedia.org/wiki/Domestic_violence

Tyson, L. (2006). Critical Theory Today: a User-Friendly Guide. (2 ${ }^{\text {nd }}$ ed.). New York, N.Y: Routledge.

Weems, C. H. (1989). The Tripartite Plight of African-American Women as Reflected in the Novels of Hurston and Walker. Journal of Black Studies, The African-American Woman: Complexities in the Midst of a Simplistic World View,20(2), 192-207. Retrieved from http://www.jstor.org/stable/2784700

Wolfenstein, V. E. (2008). How Janie Got her Groove (Back): Re Negotiating Gender, Race, and Class in Their Eyes Were Watching God [Meeting Handout]. Retrieved from http://citation.allacademic.com/meta/p_mla_apa_research_citation/2/7/7/9/8/pages277989/p277989-1.php 